\title{
Tumor cells are dislodged into the pulmonary vein during lobectomy
}

\author{
Xiaosai Yao, $\mathrm{PhD},{ }^{\mathrm{a}, \mathrm{b}}$ Christina Williamson, $\mathrm{MD},{ }^{\mathrm{e}}$ Viktor A. Adalsteinsson, BS, ${ }^{\mathrm{a}, \mathrm{c}, \mathrm{d}}$ \\ Richard S. D'Agostino, MD, ${ }^{e}$ Torin Fitton, MD, ${ }^{e}$ Gregory G. Smaroff, MD, ${ }^{e}$ Robert T. William, BS, ${ }^{a}$ \\ K. Dane Wittrup, $\mathrm{PhD},{ }^{\mathrm{a}, \mathrm{b}, \mathrm{c}}$ and J. Christopher Love, $\mathrm{PhD}^{\mathrm{a}, \mathrm{c}, \mathrm{d}}$
}

\begin{abstract}
Objective: Intraoperative tumor shedding may facilitate tumor dissemination. In earlier studies, shed tumor cells were defined primarily by cytomorphological examination, and normal epithelial cells could not always be distinguished from tumor cells. We sought to accurately identify tumor cells using single-cell sequencing and determine whether these cells were mobilized into the circulation during pulmonary lobectomy.
\end{abstract}

\begin{abstract}
Methods: Forty-two blood samples collected from the tumor-draining pulmonary vein at the end of lobectomy procedures were analyzed. Arrays of nanowells were used to enumerate and retrieve single $\mathrm{EpCAM}^{+}$cells. Targeted sequencing of 10 to 15 cells and nested polymerase chain reaction of single cells detected somatic mutations in shed epithelial cells consistent with patient-matched tumor but not normal tissue.
\end{abstract}

Results: The mean number of $\mathrm{EpCAM}^{+}$cells in video-assisted thoracoscopy (VATS) lobectomy (no wedge) specimens $(\mathrm{n}=16)$ was 165 (median, 115 ; range, $0-509)$ but sampling cells from 3 patients indicated that only $0 \%$ to $38 \%$ of the $\mathrm{EpCAM}^{+}$cells were tumor cells. The mean number of $\mathrm{EpCAM}^{+}$cells in VATS lobectomy (wedge) specimens $(\mathrm{n}=12)$ was 1128 (median, 197; range, 47-9406) and all of the $\mathrm{EpCAM}^{+}$cells were normal epithelial cells in 2 patients sampled. The mean number of $\mathrm{EpCAM}^{+}$cells in thoracotomy specimens $(\mathrm{n}=14)$ was 238 (median, 22; range, 9-2920) and $0 \%$ to $50 \%$ of total $\mathrm{EpCAM}^{+}$cells were tumor cells based on 4 patients sampled.

Conclusions: Surgery mobilizes tumor cells into the pulmonary vein, along with many normal epithelial cells. EpCAM alone cannot differentiate between normal and tumor cells. On the other hand, single-cell genetic approaches with patient-matched normal and tumor tissues can accurately quantify the number of shed tumor cells. (J Thorac Cardiovasc Surg 2014;148:3224-31)

Supplemental material is available online.

Surgical resection of a primary tumor is the first line of treatment in early-stage non-small cell lung cancer (NSCLC),

From the Koch Institute for Integrative Cancer Research, ${ }^{\mathrm{a}}$ and Departments of Biological Engineering ${ }^{\mathrm{b}}$ and Chemical Engineering, ${ }^{\mathrm{c}}$ Massachusetts Institute of Technology, Cambridge, Mass; Broad Institute of MIT and Harvard, ${ }^{\mathrm{d}}$ Cambridge, Mass; and Department of Thoracic and Cardiovascular Surgery, ${ }^{\mathrm{e}}$ Lahey Hospital and Medical Center, Burlington, Mass.

This work was supported in part by the Koch Institute Support (core) Grant P30CA14051 from the National Cancer Institute. X. Yao was supported by the National Science Scholarship from A*STAR, Singapore. V. A. Adalsteinsson was supported in part by a graduate fellowship from the National Science Foundation. J. C. Love is a Camille Dreyfus Teacher-Scholar. This work was supported by Janssen Pharmaceuticals, Inc.

Disclosures: T. Fitton reports consulting fees from Harvard Clinical Research Institute. J. C. Love reports consulting fees from Enumeral biomedical Corporation, and equity ownership in Merck, Eli Lilly, and Novartis. D. Wittrup reports consulting fees and equity from Adimab and Eleven Biotherapeutics, as well as grant support from Janssen Pharmaceuticals. All other authors have nothing to disclose with regard to commercial support.

X.Y. and C.A.W. contributed equally to this work.

Received for publication March 28, 2014; revisions received May 29, 2014; accepted for publication June 13, 2014; available ahead of print Aug 27, 2014.

Address for reprints: J. Christopher Love, PhD, 500 Main St 76-253, Cambridge, MA 02139 (E-mail: clove@mit.edu).

$0022-5223 / \$ 36.00$

Copyright (c) 2014 by The American Association for Thoracic Surgery

http://dx.doi.org/10.1016/j.jtcvs.2014.06.074 but $30 \%$ of patients relapse and succumb to distant metastases or local recurrence. ${ }^{1}$ Intraoperative tumor shedding can potentially contribute to tumor recurrence. ${ }^{2}$ Several studies have reported incidences of tumor seeding during surgery, 2,3 or local recurrences as a result of surgery. ${ }^{4}$ In particular, a study by Yamanaka and colleagues ${ }^{3}$ sampled blood through a catheter inserted into the mesenteric vein and found clusters of tumor cells released into the circulation in patients with colorectal cancers and portal invasion. In addition, a no-touch isolation technique was developed to reduce intraoperative tumor shedding. ${ }^{5,6}$ Therefore, it is of interest to quantify how many tumor cells are dislodged during the physical manipulation of the tumor during surgical resection.

In these earlier studies, shed tumor cells were identified primarily by cytomorphological examination, immunohistochemical staining, or indirect detection of epithelial cell markers such as cytokeratin and EpCAM using reverse transcription (RT)-polymerase chain reaction (PCR). ${ }^{2,7-9}$ Using cytokeratin staining, it was previously estimated that the number of tumor cells shed during surgery ranged from 10 to $7 \times 10^{6}$. 2 Another study reported a high number of tumor cells found in the pulmonary vein (mean, 1195; median, 81) using EpCAM staining. ${ }^{8}$ It remains to be determined, however, whether the tumor cell count is inflated by normal epithelial cells because none of the epithelial markers used (cytokeratin or EpCAM) are tumor 


\section{Abbreviations and Acronyms \\ MIT = Massachusetts Institute of Technology \\ NSCLC $=$ non-small cell lung cancer \\ PBS = phosphate-buffered saline \\ $\mathrm{PCR}=$ polymerase chain reaction \\ PDMS $=$ poly(dimethylsiloxane) \\ VATS $=$ video-assisted thoracoscopy \\ WGA $=$ whole-genome amplification}

specific. The lack of single-cell isolation techniques when performing genetic analysis such as RT-PCR also limits the sensitivity of detection to about 10 cells. ${ }^{9,10}$ This sensitivity may be suboptimal when the amount of tumor cells shed is extremely small.

We made use of recent advances in single-cell isolation techniques and genomic analysis ${ }^{11}$ to interrogate single epithelial cells shed intraoperatively. Whole blood was obtained from a ligated tumor-draining pulmonary vein and individual epithelial cells were isolated using arrays of subnanoliter wells (nanowells) developed previously. ${ }^{12}$ The array comprises 84,762 cubic wells of $275 \mathrm{pL}$ each. Because shed cells are rare, loading biased the occupancy of the wells to single epithelial cells. A robotic micromanipulator was then used to retrieve individual cells for single-cell targeted or whole-genome sequencing. Somatic mutations identified in this highly enriched sample of shed epithelial cells were compared against patient-matched tumor and adjacent normal tissue, allowing us to pinpoint whether the shed cells originated from the tumor.

\section{MATERIALS AND METHODS \\ Patients and Sample Collection}

Patients were recruited according to a protocol approved by the Institutional Review Board at the Lahey Hospital and Medical Center and a study at Massachusetts Institute of Technology (MIT) approved by the Committee on the Use of Humans as Experimental Subjects. The patients identified had biopsy-validated lung cancer, or had tumors suspicious for lung cancer by computed tomography scan characteristics and/or positron emission tomography scan findings and had intraoperative diagnostic wedge resections at the time of their lobectomy. Patients with lung cancer underwent lobectomy either via thoracotomy or video-assisted thoracoscopy (VATS). Once the lobe was removed, the remaining blood $(1-8 \mathrm{~mL})$ in the pulmonary vein specimen was placed in a separate EDTA tube. If the tumor was at least 1.5 $\mathrm{cm}$ in size, then a segment of tumor measuring $5 \mathrm{~mm} \times 5 \mathrm{~mm} \times 5 \mathrm{~mm}$ was removed and placed in saline and on ice. A $2 \mathrm{~cm} \times 2 \mathrm{~cm} \times 1 \mathrm{~cm}$ segment of the adjacent normal tissue was removed at least $8 \mathrm{~cm}$ outside the tumor margin. The tissue specimens were transported to MIT within 2 hours. Table 1 shows the patient characteristics (refer to Table E1 for individual patient data).

\section{Enrichment of Epithelial Cells From Blood Samples}

The blood samples were enriched for epithelial cells using RosetteSep CD45 depletion kits (Stemcell Technologies, Vancouver, Canada; refer to Online Additional Methods). After depletion of $\mathrm{CD} 45^{+}$cells, the residual cells from whole blood were stained with EpCAM, a cocktail of lineage
TABLE 1. Patient characteristics

\begin{tabular}{lc}
\hline & No. of patients $(\%)$ \\
\hline Sex & \\
Male & $17(40)$ \\
Female & $25(60)$ \\
Age (y) & \\
Mean & 66 \\
Range & $45-86$ \\
Histology & \\
Squamous cell carcinoma & $8(19)$ \\
Adenocarcinoma & $33(79)$ \\
Mixed & $1(2)$ \\
Pathologic stage & \\
I & $27(64)$ \\
II & $10(24)$ \\
III & $5(12)$ \\
Smoking history & \\
Smoker & $37(88)$ \\
Nonsmoker & $5(12)$ \\
Large vessel invasion & \\
Positive & $6(14)$ \\
Negative & $36(86)$ \\
Small vessel/lymphatic invasion & \\
Positive & $9(21)$ \\
Negative & $33(79)$ \\
Visceral pleura invasion & \\
Positive & $8(19)$ \\
Negative & $34(81)$ \\
\hline
\end{tabular}

markers (Lin) for leukocytes including CD3, CD16, CD20, CD38, and CD45 (all from Biolegend, San Diego, Calif) in a dilution of 1:20 and 1 $\mu \mathrm{M}$ Calcein Violet AM (Molecular Probes, Eugene, Ore) at room temperature for 1 hour. The cells were then rinsed with phosphate-buffered saline and stained with Annexin V FITC (BD Biosciences Pharmingen, San Diego, Calif) in Annexin V binding buffer (BD Pharmingen) for 10 minutes at room temperature.

Cells were loaded onto the array of nanowells. The entire array was imaged with an epifluorescence microscope (Carl Zeiss AG, Jena, Germany) (refer to the Online Additional Methods for imaging specifications). $\mathrm{EpCAM}^{+}$cells were identified with Enumerator, custom image analysis software developed in house. For each nanowell array, a list of cell information was generated including the well ID, cell size, and fluorescent intensities. The text file was converted into a FlowJo-readable text format. ${ }^{13}$ Gating and cell statistics were analyzed in Flowjo (TreeStar Inc, Aslnad, Ore) to identify the viable epithelial cells with their well IDs (see Figure 1, $A$, for the workflow).

\section{Single-Cell Retrieval}

Enumerator generates a list of well positions containing epithelial cells of interest. Borosilicate capillary tubing (internal diameter, 0.86 $\mathrm{mm}$; outside diameter, $1.5 \mathrm{~mm}$; length, $10 \mathrm{~cm}$; Sutter Instrument Co, Novato, Calif) was purchased and shaped with a micropipette puller (Sutter Instrument P-97). The tip was manually scored with a ceramic tile (Sutter Instrument) to achieve an internal diameter of 50 to $60 \mu \mathrm{m}$, and mounted on a robotic micromanipulator (CellCelector; AVISO GmbH, Jena, Germany). The instrument was calibrated to the position of each well of the array and instructed to retrieve the cells from the specified wells. The robot aspirated $1 \mu \mathrm{L}$ of medium directly above each well and deposited the cells into a 96-well plate for downstream assays. The capillary tube 

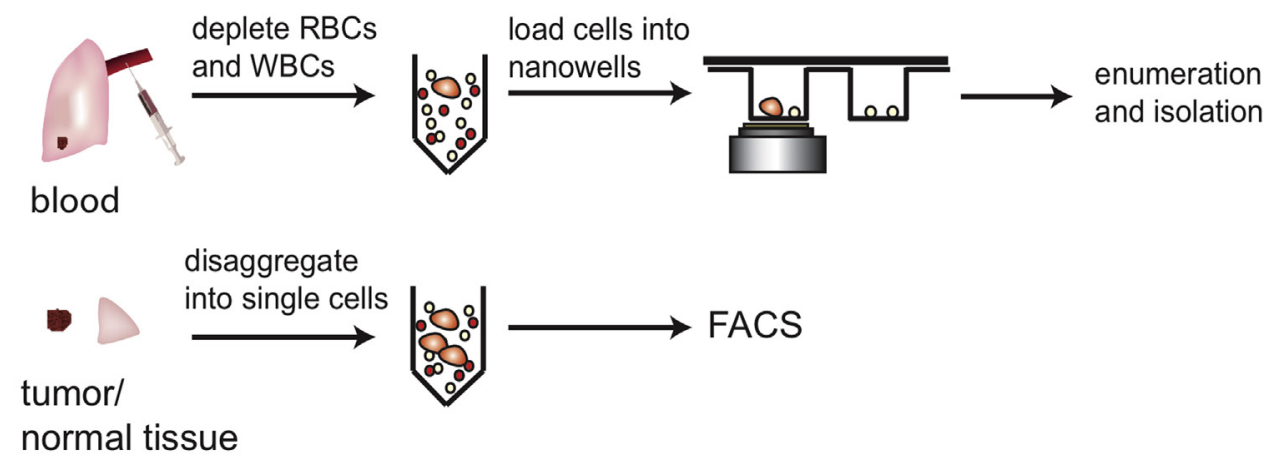

A

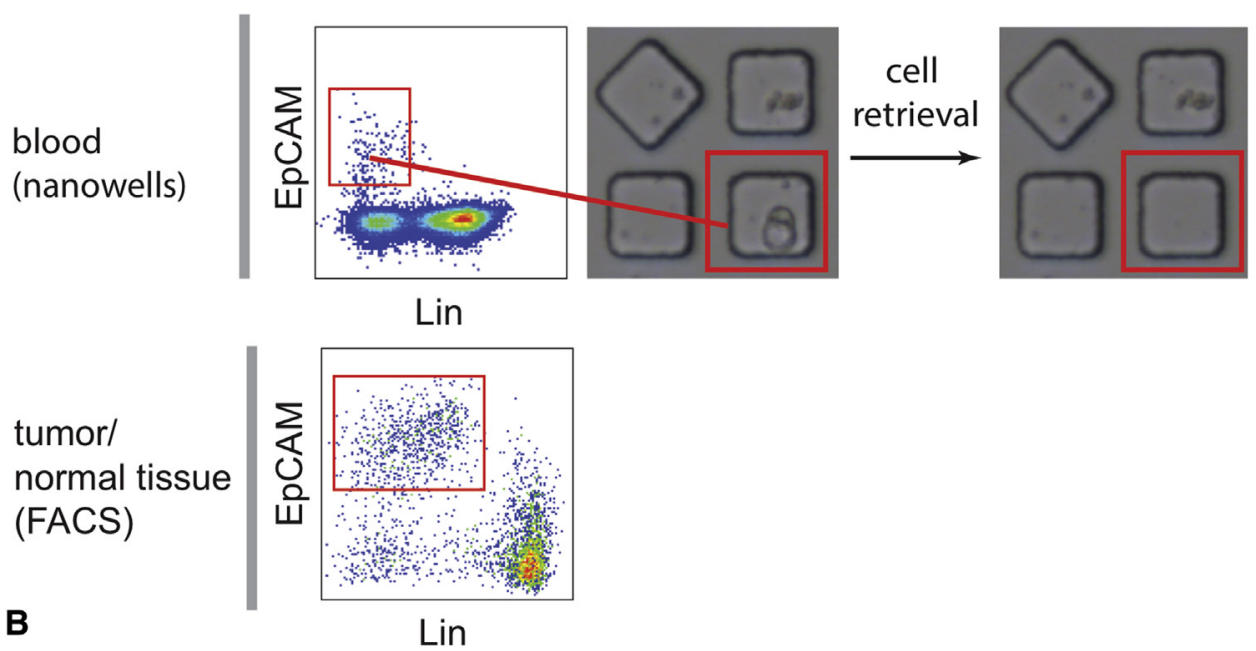

FIGURE 1. Isolation of intraoperatively shed tumor cells. A, Whole blood from the tumor-draining pulmonary vein was enriched by depletion of red and white blood cells. The remaining cells were stained with fluorescent antibodies, loaded into nanowells and imaged for enumeration of epithelial cells. Viable epithelial cells were defined as Calcein $\mathrm{AM}^{+} /$Annexin $\mathrm{V}^{-} / \mathrm{EpCAM}^{+} / \mathrm{Lin}^{-}$. Tumor and normal tissues were disaggregated into single-cell suspensions and sorted by flow cytometry using the same markers. B, Image analysis software extracted the fluorescence intensities of all the cells on the array, which could then be plotted similar to a flow cytometry plot. $\mathrm{EpCAM}^{+}$cells were gated out and a list of their corresponding well IDs was generated. Single EpCAM ${ }^{+}$ cells were retrieved with a robotic manipulator according to the well IDs. The robot only removed cells from a defined well (red box) but not from the neighboring wells. EpCAM ${ }^{+}$cells from normal and tumor tissues were harvested by flow cytometry. RBC, Red blood cells; WBC, white blood cells; FACS, flowactivated cell sorting; Lin, lineage markers.

aspirates the contents from the well of interest but not the neighboring wells (Figure 1, $B$ ).

\section{Whole-Genome Amplification}

Whole-genome amplification (WGA) was performed using the REPLIg single-cell kit (Qiagen, Limburg, The Netherlands). Ten to fifteen single cells from blood samples were deposited into a single well containing $8 \mu \mathrm{L}$ of UltraPure water (Life Technologies, Inc, Rockville, Md), $0.3 \mu \mathrm{L}$ of lysis buffer (reconstituted in $55 \mu \mathrm{L}$ of water) and $0.1 \mu \mathrm{L}$ of $1 \mathrm{M}$ dithiothreitol buffer by the robot manipulator. The volume of aspiration was reduced to $0.2 \mu \mathrm{L}$ per cell. The cells were lysed at $65^{\circ} \mathrm{C}$ for 10 minutes. Subsequently, $3 \mu \mathrm{L}$ of Stop solution was added to quench cell lysis, followed by $29 \mu \mathrm{L}$ of reaction buffer and $2 \mu \mathrm{L}$ of DNA polymerase. Isothermal amplification was carried out at $30^{\circ} \mathrm{C}$ for 8 hours.

\section{Targeted Sequencing}

Amplicon enrichment was performed using the Lung Cancer Panel within the GeneRead DNAseq Targeted Exon Enrichment Panels for
NGS (Qiagen). Library preparation was done with the NEBNext DNA Library Prep Master Mix Set for Illumina (New England Biolabs, Beverly, Mass) and barcoded with the NEBNext Multiplex Oligos for Illumina (New England Biolabs). Sequencing of barcoded pools was performed with paired-end 150 reads using the Illumina MiSeq and data were analyzed using a combination of the Cloud-Based DNAseq Sequence Variant Analysis (Qiagen).

\section{Analysis of Copy Number Variation}

WGA products were quantified using PicoGreen (Invitrogen Corporation, Carlsbad, Calif), adjusted to $2.5 \mathrm{ng} / \mu \mathrm{L}$ for library preparation using the Nextera DNA Sample Prep Kit (Illumina Inc, San Diego, Calif), and barcoded with the Nextera Index Kit (Illumina). Sequencing of barcoded pools was performed with paired-end 150 reads using the Illumina MiSeq.

\section{Mutation Analysis of Single Cells Using Nested PCR}

Single cells from blood samples were deposited into $0.8 \%$ Triton X-100 in $15 \mu \mathrm{L}$ of UltraPure water (Invitrogen) and $1 \mu \mathrm{L}$ of Proteinase $\mathrm{K}$ (600 
$\mathrm{mAU} / \mathrm{mL}$, Qiagen) by the robot manipulator as described in the cell retrieval section. Cell lysis was achieved by 1 freeze-thaw cycle and Proteinase $\mathrm{K}$ digestion for 1 hour at $55^{\circ} \mathrm{C}$. Two rounds of nested PCRs were performed to amplify the exons of interest with a multiplex PCR kit (Qiagen). The first round of PCR amplification was performed for 15 cycles (each cycle consisted of denaturation at $95^{\circ} \mathrm{C}$ for 30 seconds, annealing at $60^{\circ} \mathrm{C}$ for 4 minutes, extension at $72^{\circ} \mathrm{C}$ for 90 seconds). The second round of PCR amplification was performed for 35 cycles (each cycle consisted of denaturation at $95^{\circ} \mathrm{C}$ for 30 seconds, annealing at $60^{\circ} \mathrm{C}$ for 3 minutes, extension at $72^{\circ} \mathrm{C}$ for 90 seconds). Refer to Table E2 in the Online Data Supplement for the primers used in p53 and kras sequencing.

\section{RESULTS}

\section{Surgery Released EpCAM ${ }^{+}$Cells into the Tumor- Draining Pulmonary Vein}

Forty-two patients with early-stage NSCLC recruited in our study underwent either VATS lobectomy (with or without diagnostic wedge) or thoracotomy and lobectomy. In order to investigate whether tumor cells were shed intraoperatively, whole blood (1-8 $\mathrm{mL}$ ) removed from the ligated tumor-draining pulmonary vein was examined. Because tumor cells are rare in the blood, we developed a platform to enumerate and retrieve single cells (Figure 1). After the epithelial cells were enriched by depletion of erythrocytes and leukocytes, the remaining cells were loaded into an array of 84,672 cubic wells and imaged for surface marker expression. Viable epithelial cells in the blood were defined as Calcein $\mathrm{AM}^{+} /$Annexin $\mathrm{V}^{-} / \mathrm{EpCAM}^{+} / \mathrm{Lin}^{-}$staining. The nanowells partitioned the cells into units of single cells or preformed clusters such that the robotic micromanipulator retrieved only the viable epithelial cells from predetermined wells of interest (Figure 1,B). Epithelial cells found in normal and tumor tissues were isolated by flow cytometry for comparison with the epithelial cells found in the blood.

Enumerating the number of viable cells using the nanowells revealed a significant number of $\mathrm{EpCAM}^{+}$cells in the pulmonary vein with counts as follows: VATS lobectomy (no wedge) (mean, 165; median, 115; range 0-509), VATS lobectomy (wedge) (mean, 1128; median, 197; range, 47-9406), thoracotomy/lobectomy (mean, 238; median, 22; range, 9-2920) (Figure 2). The high number of $\mathrm{EpCAM}^{+}$cells in VATS lobectomy (wedge) was surprising initially because the tumor tissue had already been removed before the ligation of the pulmonary vein. This result implied that many $\mathrm{EpCAM}^{+}$cells were normal epithelial cells. Therefore, we needed to differentiate between normal and malignant epithelial cells using methods other than EpCAM staining to accurately quantify the number of tumor cells shed intraoperatively.

\section{Targeted Sequencing Confirmed Consistent Mutations Between Primary Tumor and Pulmonary Vein Blood After Surgery}

One accurate way to distinguish between normal and tumor epithelial cells is to look for somatic mutations

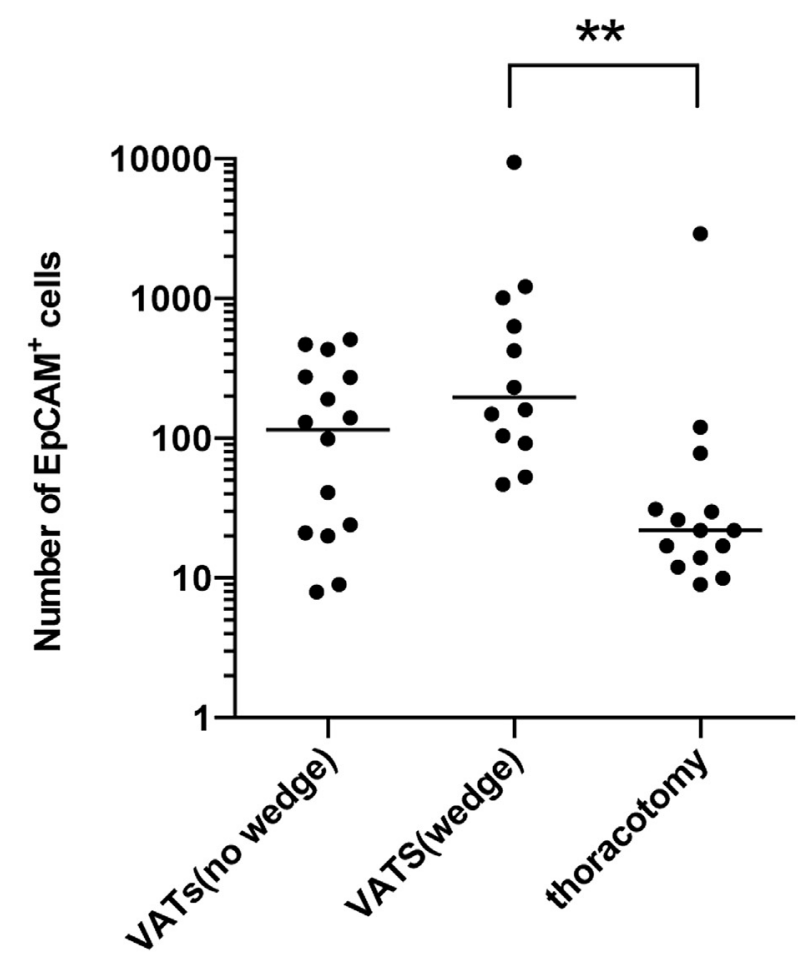

\begin{tabular}{|c|c|c|c|}
\hline & mean & median & range \\
\hline no wedge & 165 & 115 & $0-509$ \\
\hline wedge & 1128 & 197 & $47-9406$ \\
\hline thoracotomy & 238 & 22 & $9-2920$ \\
\hline
\end{tabular}

FIGURE 2. Count of $\mathrm{EpCAM}^{+}$cells in the pulmonary vein. The number of EpCAM ${ }^{+}$cells in blood from the pulmonary vein was enumerated using nanowells and plotted according to the type of surgery performed. Each bar shows the median value. One zero value is excluded from the VATS (no wedge) category. $* * P$ value $<.001$. VATS, Video-assisted thoracoscopy.

unique to tumor cells. Ten to fifteen $\mathrm{EpCAM}^{+}$cells were retrieved from the pulmonary vein of each patient and then pooled for targeted sequencing against a panel of 20 frequently mutated genes in NSCLCs. Targeted sequencing affords each gene a high coverage (typically $50 \times$ to $5000 \times$ ), enabling sensitive detection of lowabundance somatic mutations from an admixture of normal and tumor cells. The fraction of the reads mapped to the alternate alleles indicates the abundance of tumor cells (whereas the reference allele refers to the wildtype/normal phenotype).

Targeted sequencing found that only a proportion of $\mathrm{EpCAM}^{+}$cells obtained from blood harbored the same somatic mutations as the patient-matched primary tumors (Table 2). For VATS lobectomy (no wedge), $\sim 30 \%$ of the reads from 2 patients (CW46 and CW48) contained point mutations in TP53 and KRAS, respectively, whereas none of the reads from patient CW54 contained the point mutation present in the tumor. On the other hand, none of the 
TABLE 2. Targeted sequencing

\begin{tabular}{|c|c|c|c|c|c|c|c|c|c|}
\hline \multirow[b]{2}{*}{ Patient ID } & \multirow[b]{2}{*}{ Procedure } & \multirow[b]{2}{*}{ Mutations } & \multicolumn{2}{|c|}{ Tumor $(\%)$} & \multicolumn{2}{|c|}{ Normal (\%) } & \multicolumn{2}{|c|}{ Blood $(\%)$} & \multirow[b]{2}{*}{ EpCAM $^{+}$cells } \\
\hline & & & Alt & Ref & Alt & Ref & Alt & Ref & \\
\hline CW46 & VATS (no wedge) & TP53, W91* & $250(90)$ & $27(10)$ & $4(0)$ & $810(100)$ & $104(30)$ & $244(70)$ & 509 \\
\hline CW48 & VATS (no wedge) & KRAS, G12D & $298(27)$ & $804(73)$ & $0(0)$ & $860(100)$ & $495(26)$ & $1382(74)$ & 131 \\
\hline CW54 & VATS (no wedge) & KRAS, G12C & $183(39)$ & $285(61)$ & $60(4)$ & $1426(96)$ & $2(2)$ & $115(98)$ & 469 \\
\hline CW47 & VATS (wedge) & KRAS, G12C & $296(98)$ & $7(2)$ & $0(0)$ & $524(100)$ & $0(0)$ & $34(100)$ & 53 \\
\hline CW61 & VATS (wedge) & KRAS, G13C & $303(97)$ & $9(3)$ & $3(0)$ & $483(100)$ & $0(0)$ & $67(100)$ & 92 \\
\hline CW51 & Thoracotomy & TP53, R248Q & 2337 (95) & $129(5)$ & $8(0)$ & $5078(100)$ & $721(14)$ & $4370(86)$ & 31 \\
\hline CW56 & Thoracotomy & TP53, K120E & $42(20)$ & $168(80)$ & $1(0)$ & $431(100)$ & $2(0)$ & $1435(100)$ & 30 \\
\hline CW59 & Thoracotomy & STK11, Y60* & $2366(100)$ & $5(0)$ & $0(0)$ & $52(100)$ & $1(10)$ & $9(90)$ & 14 \\
\hline CW62 & Thoracotomy & EGFR, G719A & $195(17)$ & $936(83)$ & $0(0)$ & $1648(100)$ & $182(81)$ & $44(19)$ & 2920 \\
\hline
\end{tabular}

The whole-genome-amplification products of tumor, normal tissue, or shed epithelial cells found in the blood were used in targeted sequencing of 20 commonly mutated genes in NSCLC. The table indicates the number of reads mapped to the reference alleles (indicating the presence of normal cells) or alternate alleles (indicating the presence of tumor cells). Percentages of total reads are indicated in parentheses. Shown are 3 patients who underwent VATS (no wedge), 2 patients who underwent VATS (wedge), and 4 patients who underwent thoracotomy. Alt, Alternate allele; Ref, reference allele; VATS, video-assisted thoracoscopy. *Stop codon.

VATS lobectomy (wedge) samples carried somatic mutations in the blood specimens even though such mutations were present in the primary tumors, implying that wedge removed most if not all of the tumor tissue (Table 2). Therefore, all of the $\mathrm{EpCAM}^{+}$cells shed in the VATS lobectomy (wedge) procedures that we examined were normal epithelial cells.

The thoracotomy/lobectomy specimens gave a spectrum of frequencies. Patient CW56 had no detectable mutations in the blood specimen whereas patients CW51 and CW59 had approximately $10 \%$ of the reads containing the same
TP53 mutation and STK11 mutation found in their respective primary tumors. Because patients CW51 and CW59 only had 31 and $14 \mathrm{EpCAM}^{+}$cells, $10 \%$ of the total EpCAM $^{+}$cells yielded only 1 to 3 tumor cells, implying that the number of tumor cells shed in these 2 patients was almost negligible. On the other hand, the blood specimen of patient CW62 had a high proportion of reads $(81 \%)$ harboring an activating EGFR mutation at codon 719. Because patient CW62 had $2920 \mathrm{EpCAM}^{+}$cells, a significant number of tumor cells were shed intraoperatively in this patient.
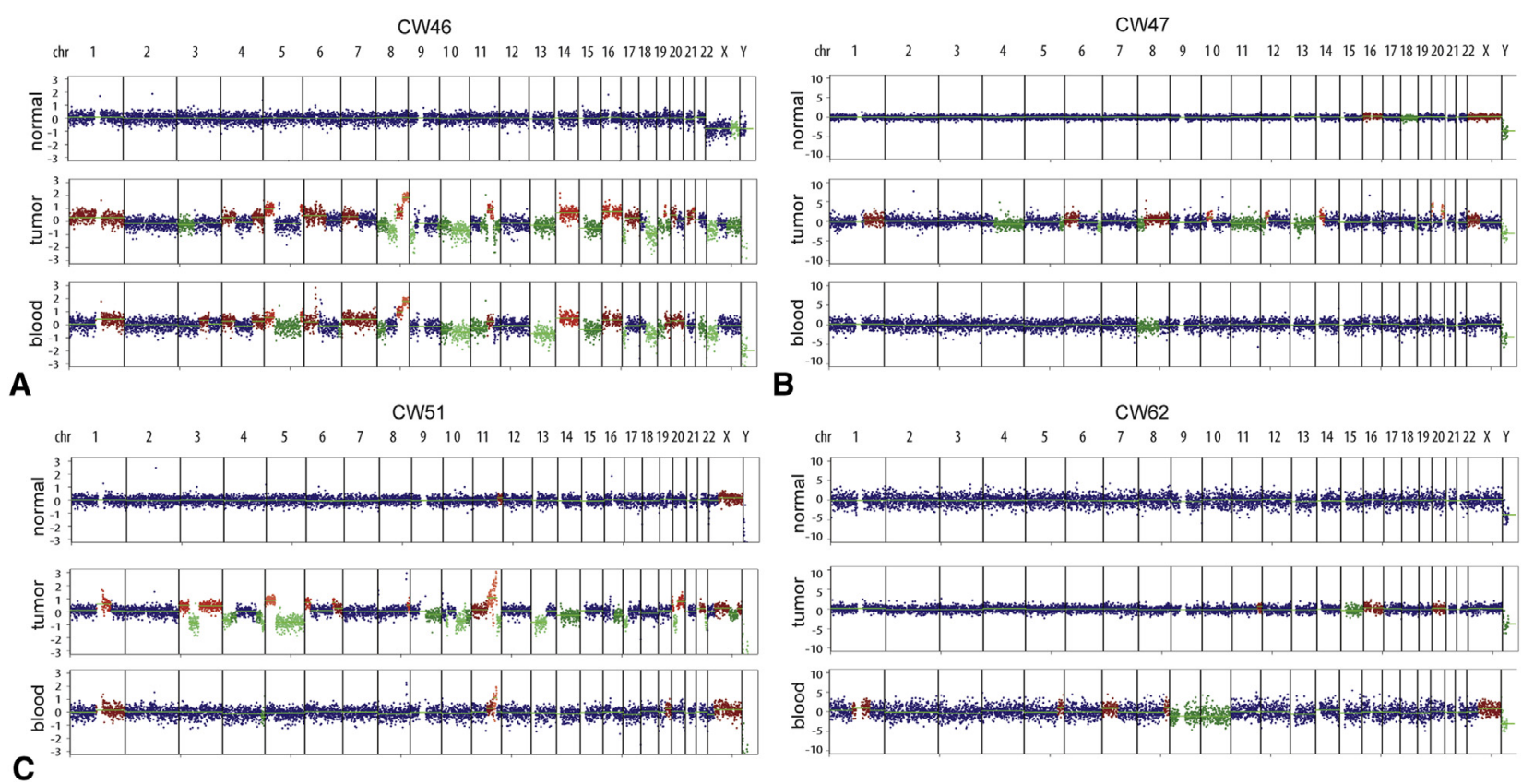

FIGURE 3. Copy number variation analysis. $\mathrm{EpCAM}^{+}$cells from normal tissue, tumor tissue, and pulmonary veins were whole-genome amplified and subjected to next-generation sequencing. The copy number variation analysis was performed with HMMCopy, a software program that segments chromosomes using a Hidden Markov Model. Chromosomal gains are colored in red; losses are colored in green; neutral copies are colored in blue. Patients underwent either: A, VATS (no wedge); B, VATS (wedge); or C, thoracotomy. 

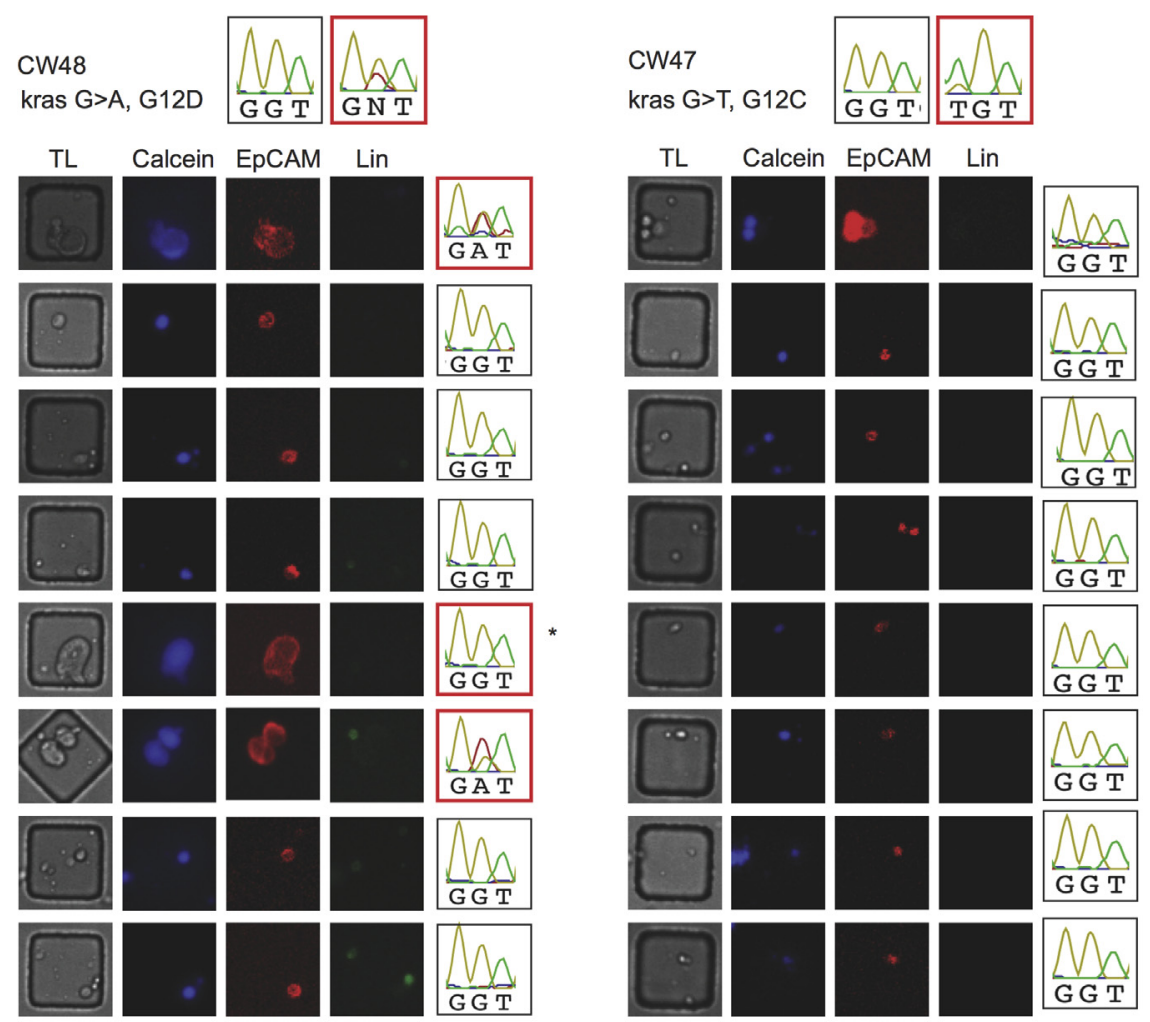

A

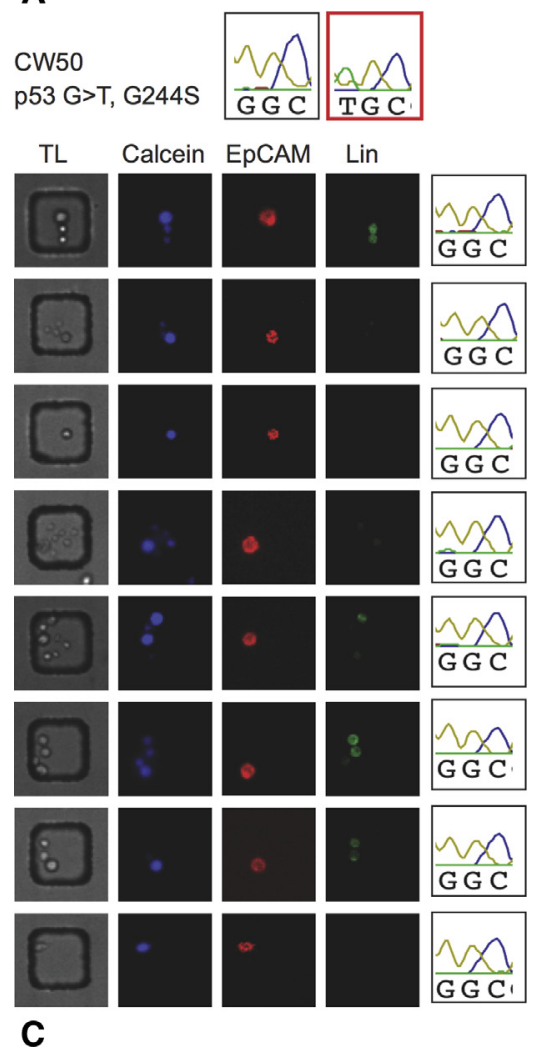

B
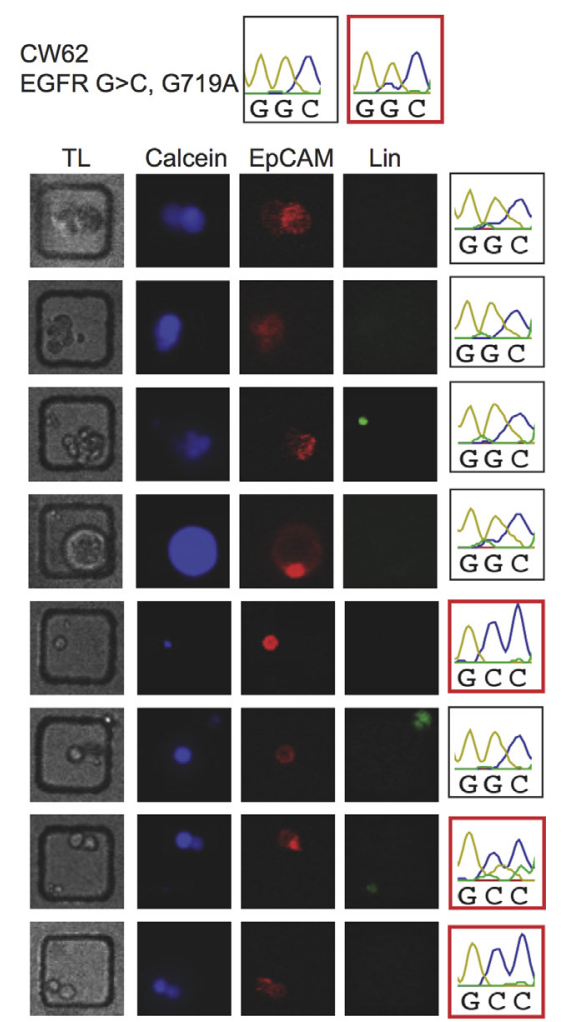

FIGURE 4. Nested PCR of single cells or single preformed clusters. The bulk tumor, normal tissue, and individual epithelial cells of the blood of 4 patients were subjected to 2 rounds of PCR amplification reactions against specific somatic driver mutations in TP53, KRAS, and EGFR. The sequences of mutated codons are indicated next to the patient ID with the normal tissue boxed in black and the tumor tissue boxed in red. The bright field and fluorescence images 


\section{Copy Number Variation Analysis Confirmed the Malignancy of Shed EpCAM ${ }^{+}$Cells in the Blood}

Although targeted sequencing identified single point mutations, copy number variation allowed us to survey the entire genomic landscape and determine the malignancy based on chromosomal gains and losses. We performed a low-pass copy number variation analysis between normal tissue, tumor, and blood.

In general, the copy number variation analysis agreed well with the targeted sequencing. In VATS lobectomy (no wedge) specimens that contained a high tumor content, such as CW46, the profile of the epithelial cells found in the blood resembled that of the tumor tissue (Figure 3, A). On the other hand, the profile of VATS lobectomy (wedge) blood specimens such as CW47 was relatively uniform (Figure 3,B), implying that no or few tumor cells were released into the pulmonary vein. For the thoracotomy/lobectomy patients with a low abundance of tumor cells in the blood, such as CW51, the profile of the blood was mostly uniform except in regions corresponding to high chromosomal gains in the primary tumor (Figure 3, $C$ ). On the other hand, patient CW62, with a high tumor content in the blood, had chromosomal aberrations in the blood specimen (Figure 3, C).

\section{Mutation Analysis of Single Cells Identified Tumor Cells Released into the Pulmonary Vein During Thoracotomy}

Although targeted sequencing and copy number variation analysis gave convincing evidence for the presence of shed tumor cells, this analysis was conducted with pools of 10 to 15 cells (mainly because of cost limitations). We developed a second method to detect somatic mutations applicable to single cells and estimate the abundance of tumor cells. Multiplex nested PCR followed by Sanger sequencing was cost effective and sensitive down to single cells. We designed multiplex primers against TP53 exons 4 to 8 , KRAS exon 2, and EGFR exons 18 to 21 because these regions contain common mutations in NSCLC. For each patient, we first confirmed the mutations present in the bulk tumors, then screened for the same mutations in single cells of the matched blood specimens.

Consistent with targeted sequencing, we detected individual tumor cells and clusters of cells in VATS lobectomy (no wedge) procedures. Two of $8 \mathrm{EpCAM}^{+}$cells from patient CW46 were tumor cells, and 3 of $8 \mathrm{EpCAM}^{+}$cells from patient $\mathrm{CW} 48$ were tumor cells (Figure 4, $A$ ). Morphologically, the tumor cells were larger and more irregularly shaped. No tumor cells were detected in the VATS lobectomy (wedge) procedures in patients CW47 (Figure 4, B) and CW61. In the thoracotomy/lobectomy samples, we did not detect single tumor cells in patients CW50 (Figure 4, C), CW56, and CW59. However, 4 of 8 EpCAM $^{+}$ cells were tumor cells and contained the activating EGFR G719A mutation in patient CW62 (Figure 4, C). Morphologically, the tumor cells were indistinguishable from normal cells, further supporting the inadequacy of using cytomorphological means to quantify the number of tumor cells.

\section{DISCUSSION}

Although previous studies have reported an abundance of intraoperatively shed cells, ${ }^{2,8}$ we used single-cell genetic means to parse these cells into normal and malignant epithelial cells. We interrogated $421 \mathrm{EpCAM}^{+}$cells from 9 patients using 3 genetic approaches: single-cell nested PCR, targeted sequencing, and copy number variation analysis. We found that lobectomy mobilizes viable tumor cells into the pulmonary vein. Other than tumor cells, a high number of normal epithelial cells were also dislodged during the surgery; these cells stained positive for EpCAM but did not contain the same driver mutations as the ones found in the primary tumors.

Many previous studies ${ }^{8,14,15}$ used EpCAM-based approaches to quantify the number of tumor cells shed during surgery. Although nearly all EpCAM ${ }^{+}$cells in the peripheral circulation (circulating tumor cells) are tumor cells, ${ }^{16}$ too many normal epithelial cells are dislodged during surgery to render EpCAM an equally good marker for intraoperatively shed tumor cells. We found no correlation between the number of $\mathrm{EpCAM}^{+}$cells shed during surgery and tumor size, lymph node metastases, blood vessel/ lymphatic invasion, or tumor grade (Figure E1), further suggesting that EpCAM is limited as a marker of surgeryinduced tumor shedding. Genetic analysis is necessary to differentiate between tumor and normal cells.

By using genetic approaches to pinpoint true tumor cells, we have identified a group of patients who have significant intraoperative tumor shedding. In our limited sample size, we found that only $20 \%$ of the thoracotomy patients ( 1 of 5 patients) had significant tumor shedding. Patient CW62 had $\sim 1000$ tumor cells mobilized into the pulmonary vein. Other thoracotomy patients either had no detectable tumor cells (CW50, CW56) or a very low number of tumor cells based on the results of targeted sequencing (CW51, CW59). A more extensive, longitudinal study is necessary

of single shed tumor cells are shown next to their sequences. Tumor cells are boxed in red. A, Patient CW48 who underwent VATS (no wedge) had 3 tumor cells. *A single tumor cell that has a mutation in KRAS F28S instead of the more prevalent G12D mutation as in the primary tumor. B, Patient CW47 who underwent VATS (wedge) had no tumor cells shed. C, Patients CW50 and CW62 both underwent thoracotomy. CW50 had no tumor cells but in CW62, 4 of the 8 cells sampled were tumor cells. TL, Transmitted light; Lin, lineage markers. 
to establish whether the number of tumor cells shed directly affects patient outcome. The sample size of our current study is too small to address this hypothesis. It also remains to be determined whether the mobilized tumor cells are capable of forming metastases.

In addition to sampling the pulmonary vein after the surgery, we also sampled the peripheral blood and pulmonary vein before surgical manipulation. However, the baseline rate of tumor shedding is low (Figure E2). Although we might not have captured all the baseline shedding using EpCAM as a marker, the disparity between the number of cells in the pulmonary vein after surgery and peripheral blood is corroborated by a previous study. ${ }^{8}$ Because the number of circulating tumor cells in patients with early-stage lung cancer is low, we believe that sampling the pulmonary vein after surgery might provide an alternative noninvasive method of identifying patients who may be at a higher risk of recurrence.

Generally, more tumor cells were detected in the pulmonary vein blood of the specimen from VATS lobectomy (no wedge) procedures than thoracotomy/lobectomy procedures. We believe that only the thoracotomy cases, not the VATS cases, truly reflect the degree of tumor cell mobilization as the manipulation of specimen after thoracotomy is minimal. Once the lobe was extracted, we were careful not to manipulate the tumor or lobe and only drained the pulmonary vein by removing the staple line from the vein. On the other hand, compression of the tumor during its extraction by a VATS lobectomy may greatly inflate the number of tumor cells shed.

The presence of mobilized tumor cells raises the question as to whether the order and timing of pulmonary vein ligation is important in minimizing this phenomenon. A recent study compared the sequence of pulmonary vessel ligation in patients undergoing thoracotomy and its impact on tumor cell shedding using CD44v6 and CK19 as the tumor marker, but the results showed no appreciable differences whether the pulmonary vein was ligated before or after the ligation of the pulmonary artery. ${ }^{17}$ It is possible that our genetic approaches may give a different count of tumor cells and reveal a difference in the degree of tumor cell mobilization during manipulation of the lobe during lobectomy.

In this study, we confirmed the presence of intraoperative tumor cell shedding by identifying consistent mutations between $\mathrm{EpCAM}^{+}$cells found in pulmonary vein blood and the patient-matched tumor. It remains to be determined whether the shed tumor cells are viable for any significant length of time in the circulation or are potentially tumorigenic and whether these mobilized tumor cells influence local or systemic recurrence.

The authors would like to thank Daniel Lai (University of British Columbia) for developing and assisting with HMMCopy, and Jie $\mathrm{Wu}$ and Charlie Whittaker from the Barbara K. Ostrom Bioinformatics \& Computing Facility (MIT) for help with data analysis.

\section{References}

1. Whitson BA, Groth SS, Duval SJ, Swanson SJ, Maddaus MA. Surgery for earlystage non-small cell lung cancer: a systematic review of the video-assisted thoracoscopic surgery versus thoracotomy approaches to lobectomy. Ann Thorac Surg. 2008;86:2008-18.

2. Hansen E, Wolff N, Knuechel R, Ruschoff J, Hofstaedter F, Taeger K. Tumor cells in blood shed from the surgical field. Arch Surg. 1995;130:387-93.

3. Yamanaka N, Okamoto E, Fujihara S, Kato T, Fujimoto J, Oriyama T, et al. Do the tumor cells of hepatocellular carcinomas dislodge into the portal venous stream during hepatic resection? Cancer. 1992;70:2263-7.

4. Matsuda A, Kishi T, Musso G, Matsutani T, Yokoi K, Wang P, et al. The effect of intraoperative rectal washout on local recurrence after rectal cancer surgery: a meta-analysis. Ann Surg Oncol. 2013;20:856-63.

5. Wang J, Mao X, Guo F, Zhang X, Guan M, Luo F, et al. An isolation technique to prevent the spread of tumor cells during radical gastrectomy for gastric carcinoma located on the anterior wall of the gastric antrum. Eur J Surg Oncol. 2013;39:1136-43.

6. Hirota M, Hashimoto D, Ishiko T, Satoh N, Takamori H, Chikamoto A, et al. Distal pancreatectomy using a no-touch isolation technique. Scand J Surg. 2012;101:156-9.

7. Sawabata N, Okumura M, Utsumi T, Inoue M, Shiono H, Minami M, et al. Circulating tumor cells in peripheral blood caused by surgical manipulation of nonsmall-cell lung cancer: pilot study using an immunocytology method. Gen Thorac Cardiovasc Surg. 2007;55:189-92.

8. Okumura Y, Tanaka F, Yoneda K, Hashimoto M, Takuwa T, Kondo N, et al Circulating tumor cells in pulmonary venous blood of primary lung cancer patients. Ann Thorac Surg. 2009;87:1669-75.

9. Brown DC, Purushotham AD, Birnie GD, George WD. Detection of intraoperative tumor-cell dissemination in patients with breast-cancer by use of reverse transcription and polymerase chain-reaction. Surgery. 1995;117:96-101.

10. Koch M, Kienle P, Hinz U, Antolovic D, Schmidt J, Herfarth C, et al. Detection of hematogenous tumor cell dissemination predicts tumor relapse in patients undergoing surgical resection of colorectal liver metastases. Ann Surg. 2005;241:199-205.

11. Shapiro E, Biezuner T, Linnarsson S. Single-cell sequencing-based technologies will revolutionize whole-organism science. Nat Rev Genet. 2013;14:618-30.

12. Love JC, Ronan JL, Grotenbreg GM, van der Veen AG, Ploegh HL. A microengraving method for rapid selection of single cells producing antigen-specific antibodies. Nat Biotechnol. 2006;24:703-7.

13. Simm M. How to roll your own FCS files. Available at: http://flowjo.typepad.com/ the_daily_dongle/2006/06/how_to_roll_you.html. Accessed November 8, 2011.

14. Fornvik D, Andersson I, Dustler M, Ehrnstrom R, Ryden L, Tingberg A, et al. No evidence for shedding of circulating tumor cells to the peripheral venous blood as a result of mammographic breast compression. Breast Cancer Res Treat. 2013; 141:187-95.

15. Galizia G, Gemei M, Orditura M, Romano C, Zamboli A, Castellano P, et al. Postoperative detection of circulating tumor cells predicts tumor recurrence in colorectal cancer patients. J Gastrointest Surg. 2013;17:1809-18.

16. Lohr JG, Adalsteinsson VA, Cibulskis K, Choudhury AD, Rosenberg M, CruzGordillo $\mathrm{P}$, et al. Whole-exome sequencing of circulating tumor cells provides a window into metastatic prostate cancer. Nat Biotechnol. 2014;32:479-84.

17. Song PP, Zhang WD, Zhang BJ, Liu Q, Du JJ. Effects of different sequences of pulmonary artery and vein ligations during pulmonary lobectomy on blood micrometastasis of non-small cell lung cancer. Oncol Lett. 2013;5:463-8. 


\section{ONLINE ADDITIONAL METHODS}

\section{Fabrication of Arrays of Nanowells}

A silicone master ${ }^{\mathrm{E} 1}$ was microfabricated (Stanford foundry) and mounted in a metal mold. Poly(dimethylsiloxane) (PDMS) (Dow Corning) (10:1 ratio of base to catalyst) was injected through a port into the silicone mold, cured at $80^{\circ} \mathrm{C}$ for 4 hours, and then removed to produce an array containing 84,672 cubic wells $(65 \times 65 \times 65 \mu \mathrm{m})$. Before use, the PDMS array was oxygen plasma treated for 2 minutes and immediately submerged in phosphate-buffered saline (PBS) to preserve the hydrophilicity rendered by the plasma treatment. The array was then blocked in serum-containing medium for 15 minutes before the cells were loaded.

\section{Tumor Disaggregation and Flow Sorting}

Tumor and adjacent normal tissues were cross-diced with a pair of scalpels, and resuspended in $2 \mathrm{~mL}$ of digest medium consisting of $1 \mathrm{mg} / \mathrm{mL}$ collagenase A (Roche) and $1 \mathrm{mg} / \mathrm{mL}$ dispase (Stemcell Technologies). The diced tissue was incubated on a shaking platform at $37^{\circ} \mathrm{C}$ for 1 hour (Figure 1, A). The digested tissue was then rinsed twice in PBS and stained with the same antibodies as the blood samples and flow sorted into a 96well plate by FACSAria III (BD Biosciences) (Figure 1, B). The sorted cells were frozen until further genomic analysis.

\section{Enrichment of Epithelial Cells From Blood}

Subsequently, $50 \mu \mathrm{L}$ of antibody cocktail was added per milliliter of whole blood and incubated for 20 minutes at room temperature. The blood was then diluted with PBS in a 1:1 ratio and layered onto Ficoll-Paque Plus (GE Healthcare, Little Chalfont, UK) in a SepMate tube (Stemcell Technologies) and centrifuged at $800 \times \mathrm{g}$ for 10 minutes. The upper layer containing the serum and buffy coat was transferred to a new tube and washed twice. Further red blood lysis was sometimes necessary to remove residual red blood cells.

\section{Microscopy}

The following wavelengths were used to image the cells seeded on the nanowells: Calcein Violet AM (excitation [Ex], $390 \mathrm{~nm}$; emission [Em], 440/40 nm), AnnexinV-FITC (Ex, 488 nm; Em, 525/36 nm), EpCAMPerCP-eFluor710 (Ex, 488 nm; Em, 716/40 nm), Lin-PE/CY7 (Ex, 570 $\mathrm{nm} ; \mathrm{Em}, 809 / 81 \mathrm{~nm}$ ).

\section{E-Reference}

E1.Ogunniyi AO, Story CM, Papa E, Guillen E, Love JC. Screening individual hybridomas by microengraving to discover monoclonal antibodies. Nat Protoc. 2009;4:767-82. 

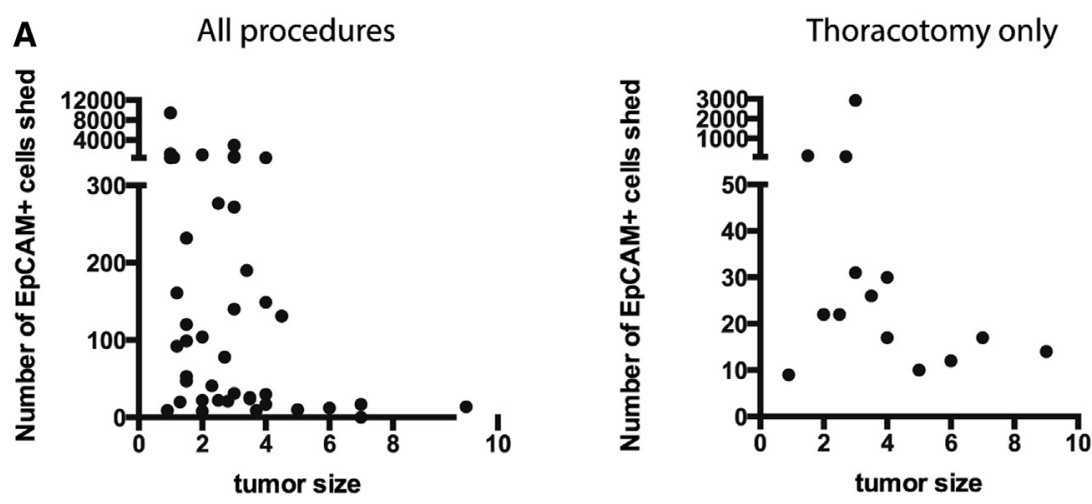

B
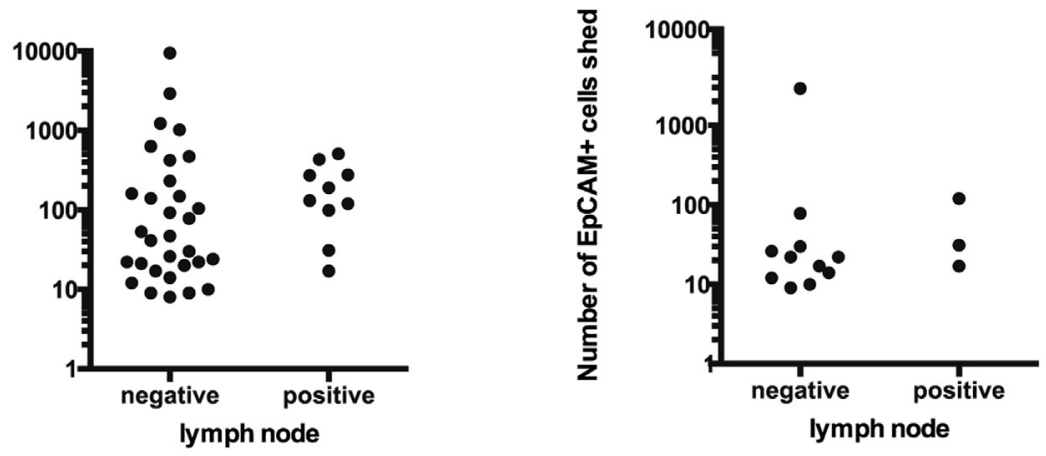

C
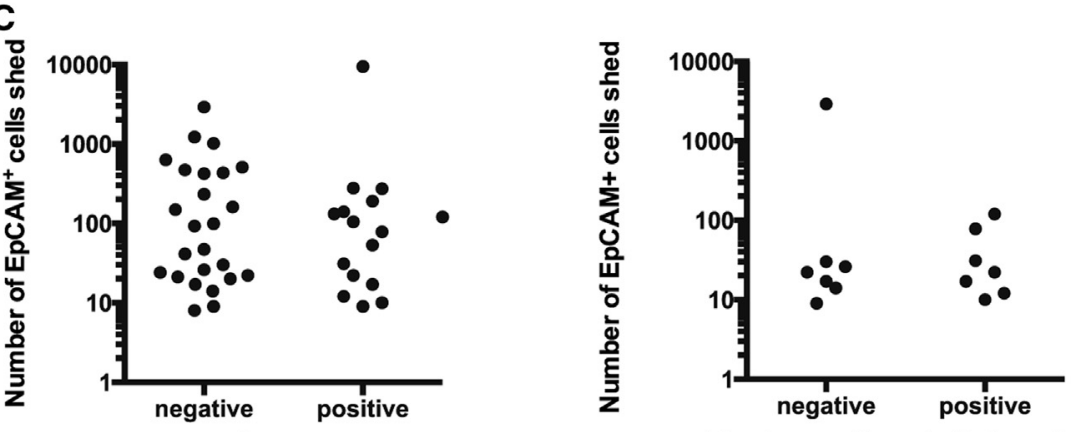

blood vessel/lymphatic invasion

blood vessel/lymphatic invasion

D
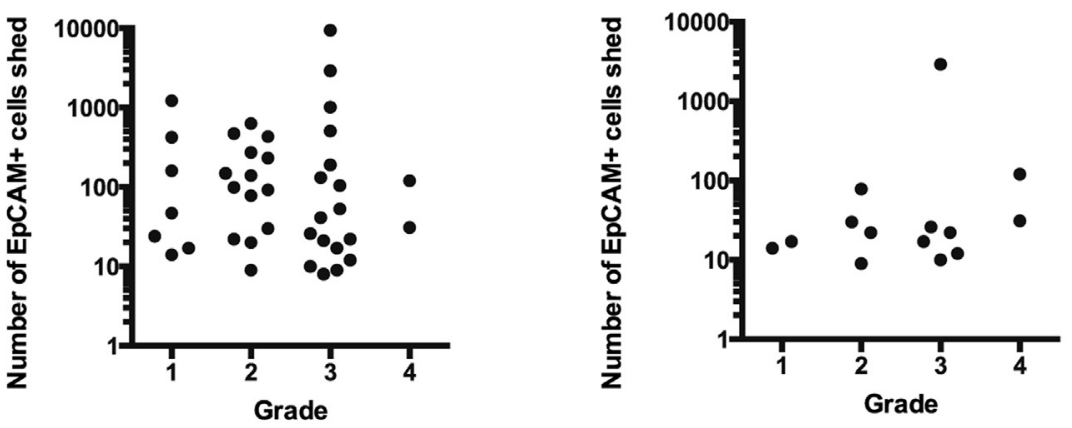

FIGURE E1. Correlation between the number of EpCAM ${ }^{+}$cells shed and histologic features (A, tumor size; B, presence of lymph node metastases; C, presence of blood vessel or lymphatic invasion; and D, tumor grade). The left panel includes all 42 patients (video-assisted thoracoscopy and thoracotomy) and the right panel includes only the patients who underwent thoracotomy (14 patients). There is no significant correlation between the number of EpCAM ${ }^{+}$ cells and the histologic features, suggesting EpCAM alone is not a good marker for quantifying the number of tumor cells shed intraoperatively. 


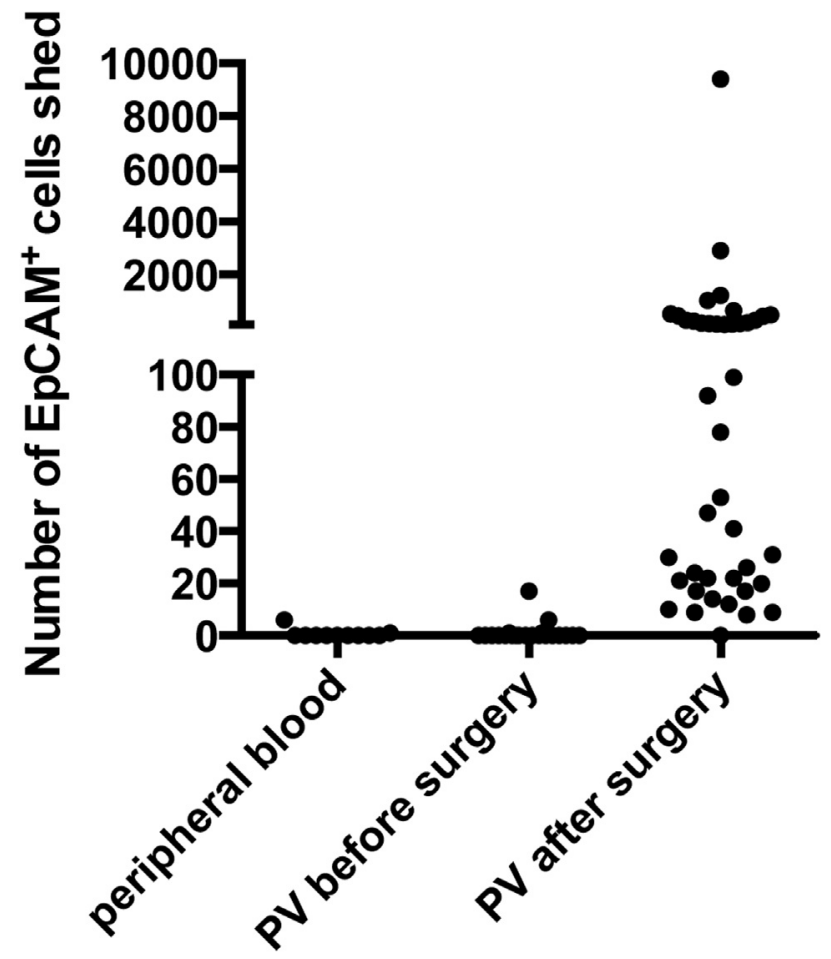

FIGURE E2. The number of $\mathrm{EpCAM}^{+}$cells shed in peripheral blood ( $\mathrm{n}=11$ patients), pulmonary vein $(P V)$ before the surgery $(\mathrm{n}=21$ patients) and the pulmonary vein after the surgery ( $n=42$ patients). The baseline shedding of $\mathrm{EpCAM}^{+}$cells is below detection in $5 \mathrm{~mL}$ of blood from most patients. 


No. of Large $\quad$ Small $\quad$ Visceral

Tumor Lobe No. of

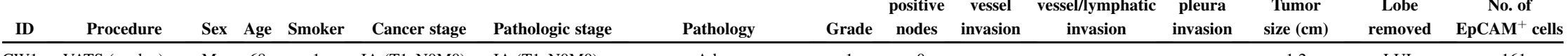

Adeno

IA (T1aNOM0) IA (T1aNOM0)

IIA (T1aN1M0) IIA (T2aN1M0)

CW4 VATS (no wedge) $\mathrm{M} \quad 73$

CW5 VATS (no wedge) M 65

CW6 VATS (no wedge) $\mathrm{F} \quad 78$

CW7 VATS (wedge) $\quad$ F 72

IB (T2aNOM0) IIA (T2aN1M0)

IA (T1aNoM0) IA (T1aNOM0)

Adeno

CW10 VATS (no wedge) M 53

IB (T2aNOM0) IB (T2aNOM0)

IB (T2aNOM0) IB (T2aNOMO)

IB (T2aNOM0) IA (T1bNOM0)

IIA (T1bNOMO) IIB (T3NOMO)

IA (T1aNOM0) IA (T1aNOMO)

IA (T1aNOM0) IB (T2aNOM0)

IA (T1aNOM0) IA (T1aNOMO)

IIB (T3NOMO) IIB (T3NOMO)

IIB (T3N0M0) IIB (T3NOMO)

IB (T2aNOM0) IIIA (T2aN2M0)

IA (T1aNOM0) IB (T2aNOM0)

IA (T1bNOM0) IA (T1bNOM0)

IA (T1aNOM0) IA (T1aNOM0)

IA (T1bNOM0) IA (T1aNOM0)

IIA (T2bNOMO) IIA (T2bNOM0)

IIIA (T1aN2M0) IA (T1aNOM0)

IA (T1aNOM0) IA (T1aNOM0)

IA (T1aNOM0) IA (T1aNOM0)

IA (T1bNOM0) IA (T1bNOM0)

IA (T1bNOM0) IA (T1aNOM0)

IIA (T1aN1M0) IIIA (T1aN2M0)

IA (T1aNOM0) IA (T1bNOM0)

IA (T1aN0M0) IIB (T2bN1M0)

IA (T1aNOM0) IB (T2aNOMO)

IIA (T1aN1M0) IIA (T2aN1M0)

IA (T1bNOM0) IA (T1bNOM0)

IIB (T3NOM0) IIIA (T3N1M0)

IIA (T1bN1M0) IIIA (T1bN2M0)

IA (T1bNOM0) IA (T1bNOM0)

IA (T1aNOM0) IA (T1aNOMO)

IIB (T3NOM0) IB (T2aNOM0)

IB (T2aNOM0) IB (T2aNOM0)

IA (T1aNOM0) IIB (T3NOMO)

IIIA (T1aN2M0) IIIA (T1aN2M0)

IIB (T3NOM0) IIB (T3NOMO)

$\begin{array}{lllllll}\text { CW60 } & \text { VATS (wedge) } & \text { F } & 63 & 0 & \text { IA (T1bNOM0) } & \text { IA (T1aNOM0) }\end{array}$

IA (T1aNOMO) IA (T1aNOMO)

Squam

Adeno

Adeno

Adeno

Adeno

Adeno

Adeno

Squam

Squam

Adeno

Adeno

Adeno

Adeno

Adeno

Squam

Adeno

Adeno

Adeno

Adeno

Adeno

Adeno

Squam

Adeno

Adeno

Adeno

Squam

Adeno

$15 \%$ squam, $70 \%$

$\begin{array}{ll}1 & 0 \\ 3 & 1\end{array}$

\begin{tabular}{|c|c|c|c|c|c|c|}
\hline 0 & & & & 1.2 & LUL & 161 \\
\hline 1 & 1 & 1 & 1 & 2.5 & RML & 277 \\
\hline 1 & & & 1 & 3 & LLL & 272 \\
\hline 0 & & & & 1.3 & LLL & 20 \\
\hline 0 & & & & 4 & LUL & 149 \\
\hline 0 & & 1 & & 3.7 & LLL & 9 \\
\hline 0 & & & & 3 & LUL & 632 \\
\hline 0 & & & 1 & 4 & RLL & 17 \\
\hline 0 & & & & 1 & LUL & 423 \\
\hline 0 & & 1 & 1 & 1 & Wedge & 9406 \\
\hline 0 & & & & 1 & RUL & 1219 \\
\hline 0 & 1 & & & 5 & RUL & 10 \\
\hline 0 & & & & 3.5 & RUL & 26 \\
\hline 3 & & 1 & & 3.4 & RLL & 190 \\
\hline 0 & & & 1 & 2.7 & RUL & 78 \\
\hline 0 & & & & 2.5 & LUL & 22 \\
\hline 0 & 1 & & & 2 & RUL & 22 \\
\hline 0 & & & & 2 & RUL & 8 \\
\hline 0 & & 1 & & 6 & Left pneum & 12 \\
\hline 0 & & & & 0.9 & RLL, RML & 9 \\
\hline 0 & 1 & & & 2 & RUL & 104 \\
\hline 0 & & & & 1.5 & LUL tri & 232 \\
\hline 0 & & & & 3.5 & RUL & 24 \\
\hline 0 & & & & 2 & RUL & 1015 \\
\hline 5 & & & & 1.5 & RUL & 99 \\
\hline 0 & & & & 2.3 & LLL & 41 \\
\hline 6 & & & & 3 & RML, RLL & 509 \\
\hline 0 & & & 1 & 1.5 & RUL & 53 \\
\hline 2 & & 1 & 1 & 4.5 & RML, RLL & 131 \\
\hline 0 & & & & 2.8 & RLL & 21 \\
\hline 2 & & & & 7 & RLL & 17 \\
\hline 8 & 1 & 1 & & 3 & RML, RLL & 31 \\
\hline 0 & & 1 & & 3 & RUL & 140 \\
\hline 0 & & & & 1.1 & RLL & 469 \\
\hline 9 & & & & 4 & LUL & 433 \\
\hline 0 & & & & 4 & RLL & 30 \\
\hline 0 & & & & 1.8 and $7 \mathrm{~mm}$ & RUL & 0 \\
\hline 10 & 1 & 1 & 1 & 1.5 & RML & 120 \\
\hline 0 & & & & 9 & RUL, RML & 14 \\
\hline 0 & & & & 1.5 & RLL & 47 \\
\hline 0 & & & & 1.2 & RUL & 92 \\
\hline 0 & & & & 3 & RLL & 2920 \\
\hline
\end{tabular}

\begin{tabular}{|c|c|c|c|c|c|c|}
\hline & & & & 1.2 & & \\
\hline 1 & 1 & 1 & 1 & 2.5 & RML & 277 \\
\hline 1 & & & 1 & 3 & LLL & 272 \\
\hline 0 & & & & 1.3 & LLL & 20 \\
\hline 0 & & & & 4 & LUL & 149 \\
\hline 0 & & 1 & & 3.7 & LLL & 9 \\
\hline 0 & & & & 3 & LUL & 632 \\
\hline 0 & & & 1 & 4 & RLL & 17 \\
\hline 0 & & & & 1 & LUL & 423 \\
\hline 0 & & 1 & 1 & 1 & Wedge & 9406 \\
\hline 0 & & & & 1 & RUL & 1219 \\
\hline 0 & 1 & & & 5 & RUL & 10 \\
\hline 0 & & & & 3.5 & RUL & 26 \\
\hline 3 & & 1 & & 3.4 & RLL & 190 \\
\hline 0 & & & 1 & 2.7 & RUL & 78 \\
\hline 0 & & & & 2.5 & LUL & 22 \\
\hline 0 & 1 & & & 2 & RUL & 22 \\
\hline 0 & & & & 2 & RUL & 8 \\
\hline 0 & & 1 & & 6 & Left pneum & 12 \\
\hline 0 & & & & 0.9 & RLL, RML & 9 \\
\hline 0 & 1 & & & 2 & RUL & 104 \\
\hline 0 & & & & 1.5 & LUL tri & 232 \\
\hline 0 & & & & 3.5 & RUL & 24 \\
\hline 0 & & & & 2 & RUL & 1015 \\
\hline 5 & & & & 1.5 & RUL & 99 \\
\hline 0 & & & & 2.3 & LLL & 41 \\
\hline 6 & & & & 3 & RML, RLL & 509 \\
\hline 0 & & & 1 & 1.5 & RUL & 53 \\
\hline 2 & & 1 & 1 & 4.5 & RML, RLL & 131 \\
\hline 0 & & & & 2.8 & RLL & 21 \\
\hline 2 & & & & 7 & RLL & 17 \\
\hline 8 & 1 & 1 & & 3 & RML, RLL & 31 \\
\hline 0 & & 1 & & 3 & RUL & 140 \\
\hline 0 & & & & 1.1 & RLL & 469 \\
\hline 9 & & & & 4 & LUL & 433 \\
\hline 0 & & & & 4 & RLL & 30 \\
\hline 0 & & & & 1.8 and $7 \mathrm{~mm}$ & RUL & 0 \\
\hline 10 & 1 & 1 & 1 & 1.5 & RML & 120 \\
\hline 0 & & & & 9 & RUL, RML & 14 \\
\hline 0 & & & & 1.5 & RLL & 47 \\
\hline 0 & & & & 1.2 & RUL & 92 \\
\hline 0 & & & & 3 & RLL & 2920 \\
\hline
\end{tabular}

277

20

large neuro, $10 \%$ small

$$
\text { Squam }
$$

Adeno

Adeno

Squam

Adeno

Adeno

$\begin{array}{llllllll}\text { CW59 } & \text { Thoracotomy } & \text { F } & 69 & 1 & \text { IIB (T3NOM0) } & \text { IIB (T3NOMO) } & \text { Adeno }\end{array}$

CW61 VATS (wedge) F 57

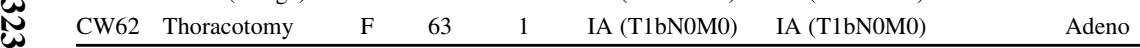

Adeno

Adeno

VATS, Video-assisted thoracoscopy; $M$, male; $F$, female; Adeno, adenocarcinoma; Squam,
$\$$ pneu, pneumonectomy; tri, trisegmentectomy; neuro, neuro-endocrine; small, small cell. 
TABLE E2. List of primers used for nested PCR of single cells to detect mutations in TP53, KRAS, and EGFR

\begin{tabular}{|c|c|c|c|c|}
\hline Gene & Exon & PCR & Direction & Sequence $\left(5^{\prime}\right.$ to $\left.3^{\prime}\right)$ \\
\hline TP53 & 4 & Outer & Forward & CTGAGGACCTGGTCCTCTGACT \\
\hline TP53 & 4 & Outer & Reverse & GGCCAGGCATTGAAGTCTCAT \\
\hline TP53 & 4 & Inner & Forward & ACCTGGTCCTCTGACTGCTCTT \\
\hline TP53 & 4 & Inner & Reverse & AAGCCAGCCCCTCAGGGCAA \\
\hline TP53 & 4 & Sequencing & Forward & CCTGGTCCTCTGACTGCTCTTTTCACCCA \\
\hline TP53 & 5 & Outer & Forward & GCTCGCTAGTGGGTTGCAGGAGGTGC \\
\hline TP53 & 5 & Outer & Reverse & TGTCGTCTCTCCAGCCCC \\
\hline TP53 & 5 & Inner & Forward & TGCTGCCGTGTTCCAGTTGCT \\
\hline TP53 & 5 & Inner & Reverse & TGTCGTCTCTCCAGCCCC \\
\hline TP53 & 5 & Sequencing & Forward & САACTCTGTCTCСТTCCT \\
\hline TP53 & 6 & Outer & Forward & GGCTGGTTGCCCAGGGTCC \\
\hline TP53 & 6 & Outer & Reverse & GGTCAAATAAGCAGCAGGAGAAAGCCCCC \\
\hline TP53 & 6 & Inner & Forward & GGCTGGTTGCCCAGGGTCC \\
\hline TP53 & 6 & Inner & Reverse & СТТААССССТССТСССАGAG \\
\hline TP53 & 6 & Sequencing & Forward & GGTCCCCAGGCCTCTGATTCC \\
\hline TP53 & 7 & Outer & Forward & GCCACAGGTCTCCCCAAGGCG \\
\hline TP53 & 7 & Outer & Reverse & AGCGGCAAGCAGAGGCTGGG \\
\hline TP53 & 7 & Inner & Forward & CGCACTGGCCTCATCTTGGGC \\
\hline TP53 & 7 & Inner & Reverse & AGTGTGCAGGGTGGCAAGTG \\
\hline TP53 & 7 & Sequencing & Forward & CCTCATCTTGGGCCTGTGTT \\
\hline TP53 & 8 & Outer & Forward & GGCTCCAGAAAGGACAAGGGTGG \\
\hline TP53 & 8 & Outer & Reverse & ATAACTGCACCCTTGGTCTC \\
\hline TP53 & 8 & Inner & Forward & TGGGAGTAGATGGAGCCTGGT \\
\hline TP53 & 8 & Inner & Reverse & CCCTTGGTCTCCTCCACCGCT \\
\hline TP53 & 8 & Sequencing & Forward & CCTTACTGCCTCTTGCTTCT \\
\hline KRAS & 2 & Outer & Forward & CGTCTGCAGTCAACTGGAAT \\
\hline KRAS & 2 & Outer & Reverse & TCATGAAAATGGTCAGAGAAACC \\
\hline KRAS & 2 & Inner & Forward & GGTGGAGTATTTGATAGTGTATTAACC \\
\hline KRAS & 2 & Inner & Reverse & GGTCCTGCACCAGTAATATGC \\
\hline KRAS & 2 & Sequencing & Forward & TTAACCTTATGTGTGACATGTTCTAA \\
\hline EGFR & 18 & Outer & Forward & GCGTACATTTGTCCTTCCAAATGAGCTGG \\
\hline EGFR & 18 & Outer & Reverse & AGATGATGGAAATATACAGCTTGCAAGGAC \\
\hline EGFR & 18 & Inner & Forward & CCGTGTCCTGGCACCCAAGC \\
\hline EGFR & 18 & Inner & Reverse & TCTGGGCTCCCCACCAGACC \\
\hline EGFR & 18 & Sequencing & Forward & TGGTGAGGGCTGAGGTGACCC \\
\hline EGFR & 19 & Outer & Forward & GCTCCACAGCCCCAGTGTCC \\
\hline EGFR & 19 & Outer & Reverse & CAGCATGGGAGAGGCCAGTGC \\
\hline EGFR & 19 & Inner & Forward & CCTTCGGGGTGCATCGCTGG \\
\hline EGFR & 19 & Inner & Reverse & GCCATGGACCCCCACACAGC \\
\hline EGFR & 19 & Sequencing & Forward & GGGCAGCATGTGGCACCATCTC \\
\hline EGFR & 20 & Outer & Forward & ACAGCCCTGCGTAAACGTCCC \\
\hline EGFR & 20 & Outer & Reverse & GCTGCATGCACGCACACAC \\
\hline EGFR & 20 & Inner & Forward & TGGCCACCATGCGAAGCCAC \\
\hline EGFR & 20 & Inner & Reverse & GGAGCGCAGACCGCATGTGAG \\
\hline EGFR & 20 & Sequencing & Forward & GCCACACTGACGTGCCTCTCC \\
\hline EGFR & 21 & Outer & Forward & AGTCACTAACGTTCGCCAGCC \\
\hline EGFR & 21 & Outer & Reverse & CAGCTGCTGCGAGCTCACCC \\
\hline EGFR & 21 & Inner & Forward & TCCTCGACGTGGAGAGGCTCAG \\
\hline EGFR & 21 & Inner & Reverse & GCAGCCTGGTCCCTGGTGTC \\
\hline EGFR & 21 & Sequencing & Forward & ACCCTGAATTCGGATGCAGAGCTTC \\
\hline
\end{tabular}

$P C R$, Polymerase chain reaction. 